\title{
Für bessere Wirkung: Stress verstärken!
}

Kleinzellige Lungenkarzinome (SCLC) fühlen sich unter replikativem Stress pudelwohl. Gleichwohl bietet sich gerade an replikativen Vorgängen die beste Chance, therapeutisch einzugreifen. Das wollen Anish Thomas und Yves Pommier auch gar nicht ändern. Aber die Thoraxexperten vom National Cancer Institute in Bethesda, MD/USA, finden, es sei „Zeit, die DNA-schädigende Chemotherapie zu überdenken." So lautet der Titel ihres Focus-Beitrags, mit dem sie auf neue Angriffsmöglichkeiten hinweisen. Immerhin rezidiviere das SCLC unter herkömmlicher Chemotherapie noch immer spätestens binnen Jahresfrist [Thomas A, Pommier Y. Sci Transl Med. 2016;8(346):346fs12]. Martin Roos

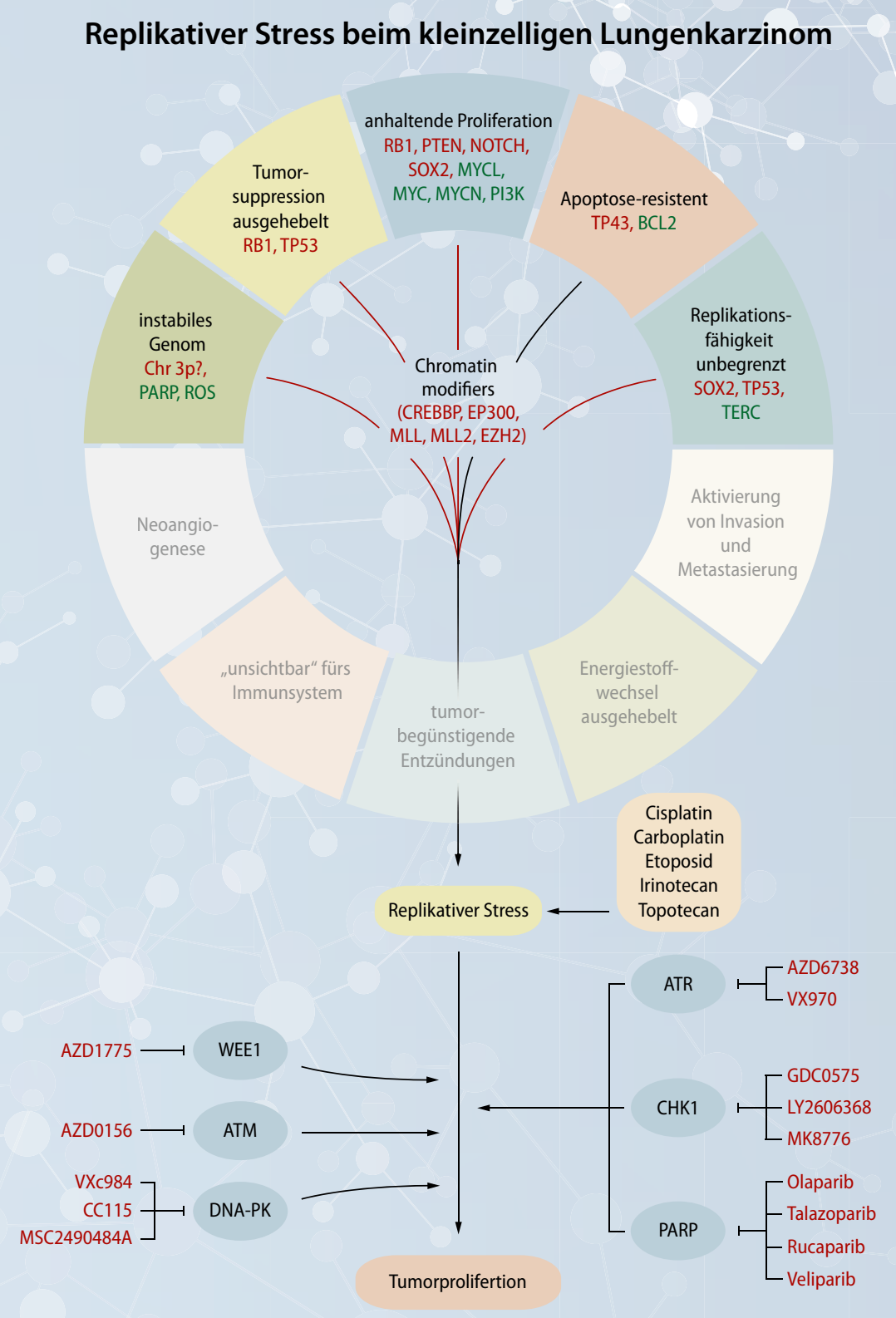

Auf mannigfaltige Weise stehen SCLC-Zellen unter replikativem Stress (Kreis; untere Hälfte von Anish Thomas und Yves Pommier nicht diskutiert). Verantwortliche Proteine liegen häufig überexprimiert vor (grün) oder aber gar nicht bzw. blockiert (rot). SCLCSignal-Mechanismen zum Tumorüberleben (Ovale) lassen sich nach Einschätzung von Thomas und Pommier durch die vermerkten Inhibitoren (zum Teil noch in der Entwicklung) aushebeln (rotbraun). In Sachen Abkürzungen verweisen wir auf den Originalartikel. 